\title{
Exploring the social function of congregations: A community development approach to develop 'hub-and-spill' early childhood development centres
}

\begin{tabular}{|c|c|}
\hline $\begin{array}{l}\text { Authors: } \\
\text { Marichen van } \\
\text { Westhuizen }^{1} \\
\text { Rina Smith } \\
\text { Jacques W. Be }\end{array}$ & der \\
\hline \multicolumn{2}{|c|}{$\begin{array}{l}\text { Affiliations: } \\
\text { }{ }^{1} \text { Department of Social Work, } \\
\text { University of the Western } \\
\text { Cape, South Africa }\end{array}$} \\
\hline \multicolumn{2}{|c|}{${ }^{2}$ Private, South Africa } \\
\hline \multicolumn{2}{|c|}{$\begin{array}{l}{ }^{3} \text { The Programme for Theology } \\
\text { and Ministry, Hugenote } \\
\text { College, South Africa }\end{array}$} \\
\hline \multicolumn{2}{|c|}{$\begin{array}{l}{ }^{4} \text { Faculty of Theology, } \\
\text { Stellenbosch University, } \\
\text { South Africa }\end{array}$} \\
\hline \multicolumn{2}{|c|}{$\begin{array}{l}\text { Corresponding author: } \\
\text { Jacques Beukes, } \\
\text { jwbeukes@hotmail.com }\end{array}$} \\
\hline \multicolumn{2}{|c|}{$\begin{array}{l}\text { Dates: } \\
\text { Received: } 17 \text { Oct. } 2017 \\
\text { Accepted: } 16 \text { Nov. } 2018 \\
\text { Published: } 20 \text { Feb. } 2019\end{array}$} \\
\hline \multicolumn{2}{|c|}{$\begin{array}{l}\text { How to cite this article: } \\
\text { Van der Westhuizen, M., } \\
\text { Smith, R. \& Beukes, J.W., } \\
\text { 2019, 'Exploring the social } \\
\text { function of congregations: A } \\
\text { community development } \\
\text { approach to develop } \\
\text { "hub-and-spill” early } \\
\text { childhood development } \\
\text { centres', HTS Teologiese } \\
\text { Studies/Theological Studies } \\
\text { 75(2), a4850. https://doi. } \\
\text { org/10.4102/hts.v75i2.4850 }\end{array}$} \\
\hline \multicolumn{2}{|c|}{$\begin{array}{l}\text { Copyright: } \\
\text { (C) 2019. The Authors. } \\
\text { Licensee: AOSIS. This work } \\
\text { is licensed under the } \\
\text { Creative Commons } \\
\text { Attribution License. }\end{array}$} \\
\hline \multicolumn{2}{|l|}{ Read online: } \\
\hline 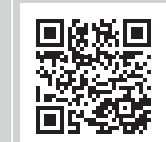 & $\begin{array}{l}\text { Scan this QR } \\
\text { code with your } \\
\text { smart phone or } \\
\text { mobile device } \\
\text { to read online. }\end{array}$ \\
\hline
\end{tabular}

This article reflects on the findings of a research study that investigated a community development project by CARITAS, a welfare organisation of the Dutch Reformed Church (DRC). The said organisation, together with local DRC congregations, and in a quest to address societal issues such as poverty and child neglect in the Northern Cape, developed early childhood development (ECD) centres in rural towns. The aim was to provide young children with quality care and to provide congregations with a platform to become active participants in community development projects. The study was conducted 5 years after the start of the project to explore the nature and value thereof. The outcomes of the study provide valuable insights regarding how such centres served as a tool to work towards ECD and a sense of community in these towns, while also addressing socio-economic issues. This article is aimed at presenting the findings as an example to be explored in other contexts.

\section{Introduction}

South Africa is faced with socio-economic issues of unemployment, poverty, hunger, crime and inequality (Statistics South Africa 2013:22). Statistics South Africa (2017) reports that more than half of South Africans were classified as poor in 2015 and that this affects, among others, children in rural areas. As a further result, the majority of young children in South Africa have been negatively impacted by a range of social and economic inequalities (Atmore, Van Niekerk \& Ashley-Cooper 2012:1). There are approximately 5.8 million children in the $0-5$-year-old age cohort. Of these, some 4.5 million children $(78 \%)$ live in circumstances of dire poverty (Barnesa et al. 2017:27).

The ongoing nature of these issues is noted by Van der Westhuizen and Swart (2015:731), who explain the historical role of the church as caregiver to vulnerable people in communities (cf. Lidzén 2008:1-7) and go on to accentuate the importance of the future role of the church to effectively address these issues through its social function in society. In order to develop this role in present-day society, Smit (2008c:105-106) notes that it is of critical importance that we investigate what congregations do and to learn from what 'average people on ground level' are doing. The importance of sharing this information has been noted by Van der Westhuizen and Swart (2015:746), who argue that the sharing of practice examples serves as a vehicle for empowerment of congregations. As a response to these viewpoints, this article aims to provide an example to be explored in other contexts and to inform future endeavours by congregations. It reports on a study that explored the nature and value of a community development project initiated by a welfare organisation of the Dutch Reformed Church (DRC) in collaboration with congregations in rural areas 5 years after the start thereof.

Firstly, a background discussion will provide a description of the focus of this article, where after the 'hub-and-spill' approach in community development as a model from which the study that informed this article was conducted will be presented. Secondly, the research methodology will be explained, followed by the findings of the study. The article will be concluded with a recommendation for future praxis.

\section{Background}

The project that informed this article was conducted from the framework of the community development approach. This approach will be discussed and linked to the social function of the

Note: This article is published in the section Practical Theology of the Society for Practical Theology in South Africa. 
church on congregational level and the concept of conviviality (i.e. 'being a community'). Principles related to convivial community development practices will be discussed, where after early childhood development (ECD) centres as a form of convivial community development will be described. These focus areas form the basis for the practice model that was used to investigate the nature and value of the ECD services, which will be presented next.

The social function of the church should evolve as communities and the socio-economic issues they face are continuously changing. Pretorius (2013:5) explains that the church preaches the gospel in relation to the specific human realities, needs, questions, problems and possibilities of the world in which congregations function. In support hereof, Smit $(2008 a, 2008 b)$ explains that one has to uniquely redefine this function, based on an understanding of the church's role within present-day society. Globally, the pressure to move towards change in our approach to societal issues furthermore includes the ongoing nature of interpersonal violence, tensions between citizens and residents, broken relationships that need to be fixed to heal societies, a society of gaps, hearing what the needs are and finding creative ways to address them, a movement from the language and praxis of welfare towards social justice and so on (cf. Ray 2014). Africa in a post-colonial era experiences an added pressure, namely to move from a Eurocentric approach to an exploration and inclusion of its own wealth of knowledge. It also challenges us to document this indigenous knowledge, skills and new ways of understanding to be included in praxis.

Elaborating on the issue of discovering and reporting on existing practices, and illuminating the church as a valuable contributor in this regard, Pretorius (2013:3-7) notes that the church has reproduced itself over centuries and can therefore be seen as a consistent role player in broader society to address the mentioned pressures. Churches should understand their engagement in the terrain or field of ECD as an exceptionally meaningful opportunity to participate in the missio Dei and, through such participation, to contribute towards the creation of a comprehensive condition of shalom (Van der Walt, Swart \& de Beer 2014:12). Pretorius (2013) and Van der Westhuizen and Swart (2015:751) suggest that the future social function of the church is directed at creating a platform where inclusion is actively pursued and where the voices of vulnerable persons and groups (children, for the purpose of this article) are being heard, where civil values (e.g. parental responsibilities) are being developed and where a sense of belonging can be experienced. The latter authors continue to recommend that the inclusion of beneficiaries of services in the planning, implementation and evaluation thereof should receive specific attention. In this way indigenous assets and potential are being developed, with a specific aim to create solidarity (i.e. a unified effort from the people living in a community) towards sustainable change (cf. Narayan, Pritchett \& Kapoor 2009:18-42).

Specifically focusing on the social function on a congregational level, Schoeman (2012:7) asserts that congregations represent the moral order, values and principles of South African citizens on grassroots level. Supporting this line of thought, the social function of congregations is described by Van Gelder (in Schoeman 2012:6) as creating a space where members of the congregation can develop and grow 'as the Spirit works to bring about transformed lives living out of a new nature'. The formational nature of this social function requires that, in particular through the practices of public worship, members of a congregation develop attributes of forgiveness, tolerance and thankfulness that emanate in a life of love, social justice and good citizenship (Smit 2008a:72-75, 2008c:105-106). Van der Westhuizen and Swart (2015) support this viewpoint and conclude that:

\begin{abstract}
... through these attributes the unique calling of congregational members is developed so that they can become a 'new community' (a koinonia) that not only cares for each other, but also develops relationships of care and solidarity (diakonia) with the weak, poor and marginalised in society. (p. 742)
\end{abstract}

Unruh and Sider (2005:28) summarise this description as 'social ministry' being an outcome of the social function of the church on congregational level, which positively affects the quality of life outside the congregation. This summary also describes the link between the social function of the church on congregational level and the community development approach.

In order to address social issues that affect human dignity and well-being effectively, long-term outcome-based strategies and sustainability that is dependent on the positive interaction between being a congregation and being a community is needed (Orsmond 2012:2). The congregation then becomes an active participant in community affairs, standing alongside others. Slenderbroek-Meints (2014:18-19) suggests that such active participation is directly dependent on the internal and external motivation of congregational members as an outcome of social ministry, the capacity of the congregation in terms of the development of networks and resources, and reaction to opportunities such as the ability to identify community needs and local resources to address those needs. In this regard, Geoghegan and Powell (2006:845) assert that while community development is aimed at satisfying needs, it particularly facilitates projects that are aimed at empowerment with the aim to, through participation strategies, attain sustainable and collective change, inclusion and equality within communities (cf. Hart 2012:55-56). The community development approach is therefore a rightsbased approach where projects are based on the willingness to take ownership of a situation and to join hands to find solutions (cf. Weyers 2011:154). In summary, community development strategies focus on the facilitation and mobilisation of stakeholders and key role players in a community to develop networks and partnerships where a variety of skills, knowledge and resources could contribute to a collaborative action towards sustainable change. This description emphasises the use of the assets within the community, instead of placing the focus on problems and deficits. It is referred to as 'asset-based community development' $(\mathrm{ABCD})$, which is further characterised by the 
identification and mobilisation of individual and community assets, skills and passions and that it is driven by relationships within the community (Kretzmann 2010:278). The ABCD approach therefore supports the value of developing a sense of being a community as a prerequisite for sustainable community development.

In line with the characteristics of the ABCD approach, this present investigation included a further preferred outcome of community development processes in that it should lead to a sense of belonging for all the members in a particular community to support the active implementation of social justice. In this regard, the term 'conviviality', coined by Illich (1977:78), refers to '.. autonomous and creative intercourse among persons, and the intercourse of persons with their environment'. The congregation as part of a group(s) within a specific community is again accentuated. This term also refers to a 'way of living' that contributes to improving and maintaining well-being. Shorthose (2002:2) draws the link between conviviality and community development as follows: Conviviality tends to focus on the everyday lives of people and acknowledges the choices they make. It tends to focus on the 'existential resources' (i.e. natural resources existing in communities) people need to carry out these everyday life choices as a central feature and to be more about what people can do for themselves. In this way, development is seen as an ongoing journey that societies, groups and individuals embark on.

Haugen (2014) adds that the art and practice of living together provides a new approach to address social issues, such as poverty and diversity. The aim is to enhance solidarity, including terms such as 'inclusion', 'social justice', 'autonomy', 'self-determination' and 'human dignity'. Other advantages of convivial communities are identified by Vipond (2012:2) as follows: Convivial communities are inclusive, and variety and diversity within the planning and use of available resources underpin the vibrant character of the convivial community. Activities are based on the interest of a wide range of people, while doing things together breaks down barriers, encourages community engagement and relies on effective coordination of activities.

Conviviality therefore means that we create opportunities where spiritual, emotional and social well-being become the preferred outcome of projects. Vaillant (2008:16) explains that services aimed at the development of a sense of specifically conviviality entails that individuals, groups and communities are guided to relate to one another with respect for values and norms. The author associates this respect with '... feelings of love, acceptance, understanding, gratitude, forgiveness, awe, truth, altruism and mutuality'. Principles of community development that relate to these values and norms include the following:

- Empowerment enhances the distribution of power and ability and provides knowledge needed to make positive decisions.

- The community will take ownership of a change process when it addresses their needs and is consistent with their ideals.
- Participation requires that a solid, local knowledge base is used, which enhances sustainability as the community benefits from its own efforts.

- Sustainability can be achieved when local knowledge and community strengths are combined. It focuses on the nurturing of the natural environment, reduction of conflict and increasing cooperation and ownership of a project by the community that leads to independence from the developer (Louw 2007:114-115; Swanepoel 2002:4-8).

The preceding discussion serves as a rationale for the use of ECD centres in communities as a way for congregations to join hands with the communities they live in. The welfare organisation of the DRC engaged in a facilitating process whereby congregations were invited to participate in the development of community-based ECD centres. The focus on ECD is supported by Martin (2015), who links such services to poverty alleviation, asserting that 'ECD services for the most vulnerable children are key to turning the tide against poverty and inequality'. Spies (2011:116) refers to the value of ECD for all children and recognises them as the future stakeholders and agents of change in communities, thereby accentuating the importance of investing in their development. In line with this viewpoint, Costin (2015) notes that investing in young children is 'one of the smartest investments a country can make to address inequality, break the cycle of poverty and improve the outcomes later in life'. Locally, this perspective is supported by the Western Cape Provincial Government Department of Social Development (2012:9), who points out that investing in ECD has been proven to be a cost-effective way to create opportunities for a better future.

Hornby (2005:1) views ECD as a form of community development and explains that it serves as an entry point towards the sustainable development of communities. Involvement of congregations in ECD services also refers to a movement from an external to an internal motivation to participate in the world we function in (cf. SlenderbroekMeints 2014:18-19). In this regard, Brink (2016:151-154) explains that we start from a conditional will and move towards an essential will that is based on hope for a better future for all. This relates to the National Development Plan's vision of finding new, innovative solutions for the socioeconomic problems facing South African communities (National Planning Commission 2011:3-5). The following statement in this plan points to not only addressing socioeconomic issues but also to working towards a sense of being a caring community, as follows:

We have created a home where everybody feels free yet bounded to others; where everyone embraces their full potential. We are proud to be a community that cares. We have received the mixed legacy of inequalities in opportunity and in where we have lived, but we have agreed to change our narrative of conquest, oppression, resistance. (National Planning Commission 2011:3-5)

The Western Cape Provincial Government Department of Social Development (2012:14-26) notes that, while an estimated $60 \%$ of children younger than 4 years do not have 
access to ECD services and come from disadvantaged households, community-based services provideopportunities for social justice to these children and their families. Furthermore, these services should not only focus on the children but should provide opportunities for training of the educators and parents, the strengthening of local resources and capacity and the development of community awareness. Congregations engaging in ECD services as part of their social function therefore enter a process of becoming part of the social realities of their communities. Discussing the potential value of developing community-based ECD services, Spies (2011:119) notes that these services are fully embedded in the community and that it becomes a potential place where different members of the community can connect, thus breaking down boundaries.

The welfare organisation of the DRC aimed to facilitate a process where the congregations could engage in the development of a community-based ECD service to actively seek a connection with the communities they exist in, while also contributing to the well-being of their communities. The next section will focus on the practical model from which this project was developed.

\section{A practical model: The hub-and-spill approach in community development}

The project that informed this article aimed to engage congregations in the development of ECD centres with the vision to (1) provide young children with quality care and (2) to provide congregations with a platform to become active participants in community development projects. This vision, the mentioned advantages of convivial communities and the link between conviviality, the community development approach and its principles relate well to Ball's (2005:12) description of ECD centres as a huband-spill approach in community development. This huband-spill approach was therefore chosen as the practice model that informed the project, as well as the exploration of the outcomes thereof.

In terms of the 'hub' concept, the ECD centre becomes a community hub where community members, as a diverse group of role players and stakeholders, come together to develop the potential of young children. The centre therefore serves as the hub from which community mobilisation takes place (Ball 2005:12-13). This hub of services focuses on the integration of services related to the needs of the children (i.e. physical, emotional, cognitive, social and spiritual needs) and developing a network of pooled resources (Ball 2005:2527). The services at the centre, together with the network of resources, then creates a space where further development is being 'spilled' from. For instance, child and youth care workers receive training, a caring community culture is developed, parental involvement and training receives attention, nutritional needs are attended to and different community services (e.g. healthcare, spiritual programmes, etc.) can be delivered from the same site (Ball 2005:28-33). Figure 1 illustrates the hub-and-spill approach used for the purpose of this article (Figure 1).

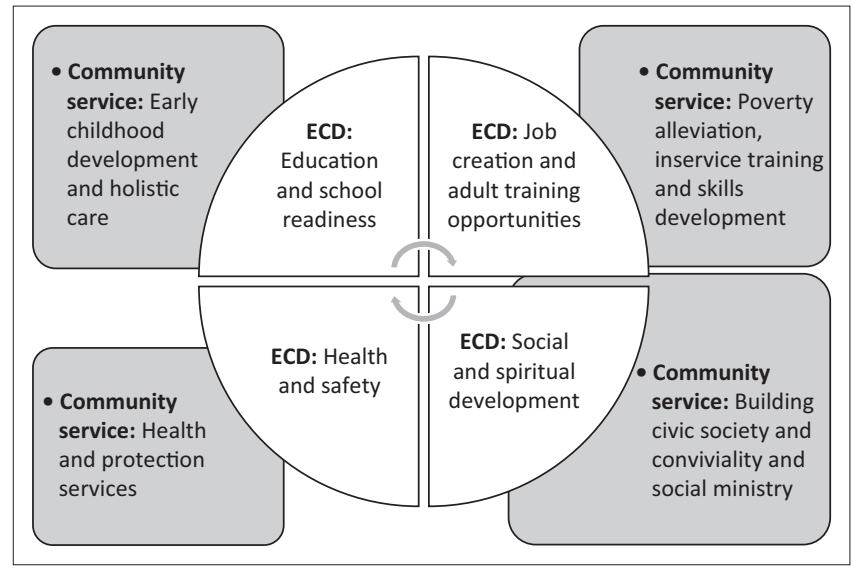

Source: Adopted from Ball, J., 2005, 'HOOK and hub: Early childhood care and development programs as "HOOK" and "hub" for inter-sectoral service delivery in First Nations communities', Journal of Aboriginal Health 2, 3-43

ECD, early childhood development.

FIGURE 1: Early childhood development services as a 'hub-and-spill' community development approach.

This article reports on an investigation of how the implementation of the hub-and-spill approach took place, as well as the outcomes thereof. The next section summarises the methodology that was employed.

\section{Methodology}

The research study's goal was to explore and describe the phenomenon of a hub-and-spill community development approach as a tool to develop ECD centres to implement the social function of congregations. A qualitative research approach was followed in an effort to develop an understanding of how persons involved experienced the development, implementation and outcome of the project (Leedy \& Ormrod 2013:94-95). A qualitative case study served as the primary research design to ensure that the project concerned be investigated and presented as a practice example from which congregations can learn (Baxter \& Jack 2008:544). The welfare organisation of the DRC, as facilitator of the process, was viewed as the case study, while the different projects were viewed as units within the case study.

The qualitative data was obtained from a purposively selected sample that represented the welfare organisation, the ECD educators, parents of children in the ECD centres and members of the communities and congregations in the Northern Cape (cf. Kumar 2014:74-75). Twenty-four participants provided the data from which the findings were developed.

This research was conducted under the auspices of the Hugenote Kollege, and ethical clearance was obtained from both the Academic Committee of the said college and the DRC's Northern Cape Synod. Once they agreed to participate, informed consent forms were signed. This was followed by semi-structured interviews with open-ended questions to focus on the development of the services, the implementation thereof in terms of the hub-and-spill approach, experiences related to the current outcomes and other related aspects that were viewed as important by the participants (cf. Greeff 
2011:351-352). The contributions were documented as field notes, which were transcribed after the interviews. The qualitative data was verified, based on the guidelines provided by Schurink, Fouché and De Vos (2011:397). The interview guide and techniques (cf. Greeff 2011:351-352) and method of data analysis supported the truth value of the data, while the research designs, sampling technique and triangulation of sources supported the transferability of the data. The interviewing techniques, documentation of the data and independent coding enhanced the neutrality of the data. The framework for qualitative data analysis proposed by Tesch (in Creswell 2009:183) was used to identify themes and subthemes. This framework consists of eight steps that lead to the description, connection and classification of the data obtained. Data were coded within the transcripts, and the codes were listed and used to identify the main themes and subthemes. The coded verbatim quotations were then placed under the relevant themes and subthemes. These findings will be presented in the following section.

\section{Findings}

The findings will be presented in terms of three main themes, focusing on the development, implementation and outcomes of ECD services from the hub-and-spill approach.

\section{The development of the early childhood development centres and services}

The subthemes describe the context and socio-economic realities of the participating communities and the process that was followed to plan and start the ECD services.

\section{The context}

The participants identified substance abuse among parents and caregivers of children as a main contributor to social problems in their communities. They explained that it often results in child neglect and parents (especially fathers) being absent from their children's lives. Crime and domestic violence, as further consequences of substance abuse, were viewed as traumatic impacts on the children's emotional well-being and safety, as well as a sign that parents are unable to express emotions of frustration, fear and powerlessness. This then results in children learning to deal with problems in an aggressive manner. An expressed concern was furthermore that foetal alcohol syndrome, as another result of parental substance abuse, limits the child's potential, which is further strained because of the substance abusing parent's inability to support the child's specific needs. Participants added that 'parents do not understand children's needs' and that many did not have access to education themselves. They further voiced the concern that social grants were not used to address the needs of the children but rather to support substance abuse among parents.

Health issues that have an impact on the children's care, functioning and development were identified as tuberculosis, HIV and AIDS. Economically, unemployment and poverty were described as factors leading to a collective feeling of hopelessness and an experience of 'it is normal to be hungry'. In terms of the socio-emotional well-being of the communities, previous projects in the community that proved to not be sustainable contributed to an attitude of apathy and a lack of involvement in community affairs. Interpersonal relationships between cultural and socio-economic groups were described as limited and distrustful.

\section{The development of the services}

This context served as a rationale to find a creative way to assist congregations to actively contribute to finding solutions to the problems experienced in their communities. The participants also noted that they experienced a need to move away from services that are dependent on government subsidies towards sustainable community development projects where communities are facilitated towards independent living. The central role of congregations to become active role players in addressing the well-being of their communities was key to the decision to develop the project. Additionally, the participants reflected that the initial motive was based on a belief that sustainable change in communities would be possible if children were empowered through education, safety and physical, emotional and spiritual care. They explained that, while the immediate needs of the children would be addressed, a long-term result would be that the children's potential would be developed.

The participants explained that a clear vision of preferred outcomes of the project guided the planning process. These outcomes are as follows:

- the development of children's potential at an early stage to ensure success in their school careers

- community-based protection and care of young vulnerable children

- the involvement of different systems, stakeholders and role players to create a sense of being a community (i.e. conviviality)

- creating job opportunities for members of the community, including capacity building through training in ECD practice

- the development of a joint community project, with shared responsibilities and investments

- sustainable development that results in 'positive stories of finding own solutions to socio-economic problems'.

The following process was followed: The welfare organisation, with the support of the DRC's Northern Cape Synod, facilitated the process by presenting the idea to different church leaders. Willing church leaders started an awareness process in the congregations. The participants explained that it became 'an opportunity for the congregation to go to the world through the ECD centre' and that it became a practical means for congregations to become 'involved in the needs of others'. Congregations identified ways to become involved in terms of infrastructure (e.g. buildings) and volunteer support (e.g. soup kitchens to provide children and their families with food). The data also highlights the fact that while some congregations immediately became actively 
involved, other congregations became involved gradually. As congregational members saw the needs of their fellow community members and the value of the ECD centres to address these needs, the internal motivation became stronger.

The community development approach as a guiding framework placed the emphasis on including different systems in the project (i.e. parents, community volunteers, congregations, service providers, etc.). The social worker of the welfare organisation was initially key to planning the projects, informing members of the congregations and communities, and preparing staff and volunteers. Congregational leaders were key to preparing members for moving towards active participation.

\section{The implementation of the early childhood development services}

In line with the principles of community development, the management of the centres was described as a collaborative effort. Existing role players and structures that informed the management of the services included the welfare organisation of the DRC, in terms of management of the planning and monitoring of services. Additionally, the social worker facilitated training opportunities and acted as a mentor to the staff, who were members of the community. Congregational members acted as volunteers who provided skills (hub point), services to the children and their parents (spill point) and shared knowledge and expertise. Staff and parents were also involved in the day-to-day management of the services. Focus areas of management were identified as administrative, maintenance, financial, services to children and staff development.

The participants reported that ownership by the broader community had not developed fully, and that the congregations were still taking the main responsibility. However, they recommended that it be seen as a gradual process. They reported that, by involving the parents and congregational members as volunteers, the message of the value of the services was being spread, leading to a greater level of support from the broader community. An example of community involvement was mentioned where a member of the South African Police Service became aware of the service and started to promote and support the service. Congregational members, as members of the community, were involved in terms of projects to collect donations, spiritual programmes to the children, emotional support to children and parents, advice and support to staff and maintenance tasks. Parents as members of the community often represented the mentioned apathy. Successes were reported where parent committees were formed. These committees then became responsible for maintenance and fundraising activities.

\section{Experiences related to the current outcomes in terms of the hub-and-spill approach}

The participants described ECD centres as safe places where needs of nutrition, security and love were being addressed.
A participant explained that the home-like environment provided children with a dream of a better life. The involvement of the parents influenced the children's development, as parents learned to stimulate, support and protect their children. This was described as an indirect form of parental learning.

As mentioned before, the participants noted that ownership and participation requires an awareness process over time. They referred to the interaction between the ECD centre, the congregation and parents as a move towards conviviality. The members of the congregation, through the mentioned involvement at the centres, engaged with parents who were non-members of the congregation, which led to bridging the gap between groups in the community. The participants explained how the members of the congregation, as a result of the development of an awareness of the value of the ECD centre, encouraged their employees to enrol their children at the centre. In this way, the central role of the ECD centres was to develop and nurture the relationship between the congregation, employers and employees. The interactions described point to a movement towards the hub-and-spill approach to community development.

\section{Early childhood development as hub-and-spill community-based centres}

The participants explained that the ECD centres served as a hub point in that they created a safe and homely atmosphere for the children where physical care, educational stimulation and development and social development received attention. They reported that children who entered the school system after exposure to ECD programmes adapted well. This then led to teachers promoting the use of the service within the communities. The hub point was also extended to parents, who normally would not be able to afford ECD services. Parental awareness and involvement was a main focus of the staff, with the aim to develop parental skills that would influence the communities' well-being further. Additionally, social justice was practised as parents were treated with respect and an attitude of belief that they could develop and grow themselves. The congregational and community members expressed the services as a hub point in terms of the accessibility of the services, job opportunities that were being created, training opportunities for staff and parents, and the availability of educational opportunities for the children of the communities. The participants further reported a 'change in the minds and hearts' and 'a movement closer to each other in the community', explaining that the mentioned hub points indicated a gradual movement towards an awareness that change is possible and tolerance between groups in the community.

Spill points that evolved from the ECD services were reported to develop slowly. Parental guidance, marriage counselling and spiritual formation activities were identified as services directed at the parents. Schools benefited through the ECD programmes, as readiness for school was noted. Indirect spill points were identified in terms of the improvement of human dignity where parents felt proud of the opportunities 
provided to their children and opportunities where they learned indirectly through the development of their children. The contact between different groups in the community was also described as an indirect service provided at the ECD centres. Reports also pointed to the ECD centre acting as a community source - for example, by becoming involved in recycling projects in the community.

\section{Challenges experienced}

The need for formal training opportunities for staff was identified, while the participants acknowledged the fact that staff members were able to creatively develop the services. Financial independence also remained a challenge. This is described as a symptom of poverty within the communities on the one hand, and because of the slow process of engaging the whole community on the other hand. The participants recommended that a realistic expectation should be that both parental and community participation and ownership must become a focus of services and that this requires a long-term effort.

The concluding recommendations that follow emanated from the findings discussed in this section.

\section{Concluding recommendations for future praxis}

This case study provided a context-related practice example of how the hub-and-spill community-based ECD centre can serve as a tool for congregations to become active participants in the social realities of the communities they live in and promote community development. While a movement towards conviviality was noted, it was acknowledged that it required a focused, long-term effort. The reality of disillusionment from past experiences where projects failed, long-standing mistrust between groups (cf. Motloung 2013:2) and a culture of apathy and hopelessness must be considered and addressed through social ministry. Furthermore, Mthembu (2010:31-32) draws a link between apathy and the influence of the apartheid era. This author explains that we cannot ignore the fact that historic socio-economic developments resulted in present-day interactions that reflect a continued notion of one group ultimately deciding the fate of others. One can therefore conclude that the community members are still affected by this history, resulting in an inability to know how to have a say in their own lives. White (2009:5-11) explains that although institutional leaders, such as church and NGO leaders, could have a genuine desire to include community members in the planning and implementation of actions that will benefit them, these efforts often do not result in an authority to decide what the plan should entail. This author, however, advises that personal interactions could provide an opportunity for the real sharing of power.

Additionally, the social realities of substance abuse, crime, violence, poverty and unemployment (cf. Van der Westhuizen 2013,2015 ) necessitate that congregations find creative ways of participating in finding solutions that are based on the principles of their social function within communities.
A key function of congregational leaders is to assist members to move from an external to an internal motivation to care about and participate in the social realities of their communities (cf. Slenderbroek-Meints 2014:18-19). Involvement in existing ECD projects or the development thereof provides a practical platform from which interactions between different community stakeholders can develop, while relationships can develop in terms of working towards a common goal and social issues being addressed through the development and mobilisation of internal resources (cf. Weyers 2011:154-155).

ECD centres provide children with a safe place where their cognitive, physical, emotional, social and spiritual formation can be nurtured. Congregations have access to these children to guide their spiritual formation, while also contributing in addressing their basic needs. Congregants are therefore active participants in the lives of children. Active involvement with children also implies participation by parents and members of the community.

Projects should start small and manageable, while existing resources (infrastructure, expertise, skills and donations) should be identified, mobilised and coordinated (cf. Weyers 2011:154-155). Starting small provides opportunities for experiencing successes. By identifying and mobilising internal congregational resources, the congregation supports the ECD service as a hub point where services are provided. Congregations can further participate through volunteer services to the children, parents and staff, and by supporting the services (e.g. making use of the ECD services themselves).

Involvement in the actual services to the children and their parents also serves as a spill point, where the congregation becomes an active role player in community affairs. The social function of the congregation is then extended to building networks in the community, where the community members are guided towards internal motivation to support the services. In an effort to actively engage with different groups in the community, the ECD centres can be used where congregations facilitate contact between different groups and where services of benevolence can be rendered to the advantaged of the broader community. Congregants can become involve in the forming of playgroups and other practical ways of illuminating the church's focus on ECD.

In summary, the findings highlight the potential of ECD services to form a community hub-and-spill point where congregations can become an active part of community activities. The healing of interrelations between groups in a community requires time, persistence and a safe space for developing awareness and tolerance. In this regard, ECD services serve as a hub that draws community members to the project, while outcomes (spills) include the development of children's potential, addressing social issues such as poverty, unemployment and substance abuse and creating a space for community members to move closer to each other. Through the development of such relationships, reciprocal 
learning and service can take place, and a platform for further community development projects can be created.

\section{Acknowledgements Competing interests}

The authors declare that they have no financial or personal relationship(s) that may have inappropriately influenced them in writing this article.

\section{Authors' contributions}

M.v.d.W. and R.S. were responsible for the research process design; J.W.B. contributed to the theoretical framework of the research study; R.S. was responsible for the implementation of the research process; M.v.d.W. was responsible for the data analysis; and M.v.d.W., J.W.B. and R.S. collaborated to interpret the findings.

\section{References}

Atmore, E., Van Niekerk, L. \& Ashley-Cooper, M., 2012, 'Challenges facing the early childhood development sector in South Africa. A Comprehensive Research report on Early Childhood Development to the National Development Agency (NDA)', South African Journal of Childhood Education 2(1), 120-139.

Ball, J., 2005, 'Hub and hub: Early childhood care and development programs as "hub" and "hub" for inter-sectoral service delivery in First Nations communities', Journal of Aboriginal Health 2, 3-43.

Barnesa, H., Hallb, K., Sambub, W., Wrighta, G. \& Zembe-Mkabilec, W., 2017, Review of research evidence on child poverty in South Africa, Children's institute, University of Cape Town, Cape Town.

Baxter, P. \& Jack, S., 2008, 'Qualitative case study methodology provides tools for researchers to study complex phenomena within their contexts', The Qualitative Report 13(4), 544-559.

Brink, S., 2016, 'Employing a multifocal view of ECD curriculum development at a rural settlement community in South Africa: Themes from a "design by implementation" early childhood education programme', South African Journal of Childhood Education 6(1), 148-170.

Costin, C., 2015, Levelling the playing field from the start: The power of Early Childhood Development, viewed 25 August 2016, from www.worldbank.org/en/about/ people/claudia-costin

Creswell, J.W., 2009, Research design: Qualitative, quantitative, and mixed methods approaches, 3rd edn., Sage, Los Angeles, CA.

Geoghegan, M. \& Powell, F., 2006, 'Community development, partnership governance and dilemmas of professionalization: Profiling and assessing the case of Ireland', British Journal of Social Work 36, 846-861. https://doi.org/10.1093/bjsw/bch344

Greeff, M., 2011, 'Information collection', in A.S. De Vos, H. Strydom, C.B. Fouché \& C.S.L. Delport (eds.), Research at grass roots, for the social science and human service professions, pp. 341-375, 4th edn., Van Schaik Publishers, Pretoria.

Hart, C.S., 2012, 'Professionalisation of community development in South Africa: Process, issues and achievements', Africanus 42(2), 55-66.

Haugen, H.M., 2014, 'Conviviality: A new approach to understand community living? Methods for working with marginalised persons and communities', in Presentation at 5th Biennial Conference for Research in Diaconal and Christian Social Practice, Ersta Sköndal University College, Stockholm, September 17-20, 2014, pp. 4-6.

Hornby, D., 2005, A community development approach to early childhood: Childrenour future communities. Work 2005: The Expanded Public Works Programme in the Social Sector, Human Science Research Council (HRSC), Cape Town.

Illich, I., 1977, Toward a history of needs, Heyday Books, Berkley, CA.

Kretzmann, J.P., 2010, 'Asset-based strategies for building resilient communities', in J.W. Reich, A. Zautra \& J.S. Hall (eds.), Handbook of adult resilience, Guilford Press, New York.

Kumar, R., 2014, Research methodology: A step by step guide for beginners, 4th edn., Sage, London.

Leedy, P.D. \& Ormrod, J.E., 2013, Practical research: Planning and designing, 10th edn., Pearson Education Limited, New Jersey.

Lidzén, L., 2008, A comparative study of the social welfare provided by three Christian churches in Accra, Ghana, Institutionen för humaniora och samhällsvetenskap, Högskolon I Grave.

Louw, H., 2007, Participatory community development in social work and the social service professions, University of South Africa, Pretoria.

Martin, P., 2015, Early childhood development: The children can't wait, viewed 21 August 2016, from groundup.org.za/early-childhood-development-children-can'twait_3192.
Motloung, B., 2013, Cultural tolerance and the South African experience, South African Embassy in Bulgaria, Sofia.

Mthembu, N., 2010, A dream of Azania: Political and socio-economic struggles in postapartheid South Africa, Reach Publishers, Wandsbeck, South Africa.

Narayan, D., Pritchett, L. \& Kapoor, S., 2009, Moving out of poverty, Volume 2: Success from the bottom up, The World Bank and Palgrave Macmillan, Washington, DC.

National Planning Commission, 2011, National development plan 2030, Office of the Presidency, South African Government, Pretoria, viewed 21 September 2016 from http://www.gov.za/sites/www.gov.za/files/npc_diagnostic_overview_1.pdf

Orsmond, E., 2012, 'The church and community development - Challenges with others', Presentation delivered at the Symposium 'Theology in times of change', Faculty of Theology, Stellenbosch University, Stellenbosch, January 23, 2012, pp. 1-5.

Pretorius, D., 2013, 'Revitalising the role of the church in socio-economic development', A presentation to church leaders, Victory Ministries International,
Port Elizabeth, 11 July 2013, viewed 16 June 2015, from http://tcn.org.za/wpPort Elizabeth, 11 July 2013, viewed 16 June 2015, from http://tcn.org.za/wp
content/uploads/2013/07/Development-Strategy-for-Metro-10-7-13-02.pdf

Ray, H., 2014, 'Recent policy and politics of the European Union and effects on welfare: Implications for research', Presentation at 5th Biennial Conference for Research in Diaconal and Christian Social Practice, Ersta Sköndal University Research in Diaconal and Christian Social Practice,
College, Stockholm, September 17-20, 2014, pp. 1-4.

Schoeman, W.J., 2012, 'The involvement of a South African church in a changing society', Verbum et Ecclesia 33(1), Art. \#727, 8 pages. https://doi.org/10.4102/ society', Verbum
ve.v3i1.727

Schurink, C.B., Fouché, C.B. \& de Vos, A.S., 2011, 'Qualitative data analysis and interpretation', in A.S. De Vos, H. Strydom, C.B. Fouché \& C.S.L. Delport (eds.), Research at grass roots, for the social science and human service professions, pp. Research at grass roots, for the social scien
$397-430,4$ th edn., Van Schaik, Pretoria.

Shorthose, J., 2002, 'Conviviality in global cultural development: Diversity, freedom and agency', Development: The International Journal of Development Studies 45(3), 1-12. https://doi.org/10.1057/palgrave.development.1110381

Slenderbroek-Meints, J., 2014, Onderzoek binnen de CGK, NGK en GKV naar huidig en gewenst diaconaat en wat daarvoor nodig is, Centrum voo Samenlevingsvraagstukken, Zwolle, viewed 16 June 2015, from http://www.viaa. $\mathrm{nl}$ / /media/Files/Onderzoek/CvSv/Publicaties/14_0310_HELP.ashx

Smit, D.J., 2008a, 'Oor die kerk as ' $\mathrm{n}$ unieke samelewingsverband', in D.J. Smit (ed.), Geloof en Openbare Lewe. Versamelde Opstelle 2: Spesiale uitgawe in die Beyer Naudè Centre Series on Public Theology, pp. 69-81, SUN Press, Stellenbosch.

Smit, D.J., 2008b, 'Oor die unieke openbare rol van die kerk', in D.J. Smit (ed.), Geloof en Openbare Lewe. Versamelde Opstelle 2: Spesiale uitgawe in die Beyers Naudè Centre Series on Public Theology, pp. 83-99, SUN Press, Stellenbosch.

Smit, D.J., 2008c, 'Oor die kerk en maatskaplike uitdagings in ons land', in D.J. Smit (ed.), Geloof en Openbare Lewe. Versamelde Opstelle 2: Spesiale uitgawe in die Beyers Naudè Centre Series on Public Theology, pp. 101-114, SUN Press, Stellenbosch.

Spies, M., 2011, 'Early childhood development as a pathway to sustainable community development', Unpublished thesis for Master of Philosophy (Sustainable Development Management and Planning), University of Stellenbosch, Stellenbosch.

Statistics South Africa, 2013, Millennium Development Goals Country Report 2013: The South Africa I know, the home I understand, Statistics South Africa, Pretoria, viewed 12 December 2014, from www.statssa.gov.za/MDG/MDGR_2013.pdf

Statistics South Africa, 2017, Poverty on the rise in South Africa, viewed 12 December 2014, from http://www.statssa.gov.za/?p=10334.

Swanepoel, H., 2002, Community development: Putting plans into action, Juta and Company Limited, Cape Town.

Unruh, H.R. \& Sider, R.J., 2005, Saving souls, serving society: Understanding the faith factor in Church-based social ministry, Oxford University Press, New York.

Vaillant, G.E., 2008, Spiritual evolution: A scientific defence of faith, Random House, New York.

Van der Walt, J.P., Swart, I. \& de Beer, S., 2014, 'Informal community-based early childhood development as a focus for urban public theology in South Africa', Special collection on 'Doing urban public theology in South Africa: Visions, approaches, themes and practices towards a new agenda', HTS Teologiese Studies/Theological Studies 70(3), 2014

Van der Westhuizen, M.A., 2013, Die betrokkenheid van die NG Kerk by die stryd teen armoede, werkloosheid en maatskaplike ongeregtigheid, General Synod of the Dutch Reformed Church and Hugenote Kollege, Wellington.

Van der Westhuizen, M.A., 2015, Die maatskaplike impak van kerklike programme op armoede, werkloosheid en maatskaplike ongeregtigheid, General Synod of the Dutch Reformed Church and Hugenote Kollege, Wellington.

Van der Westhuizen, M.A. \& Swart, I., 2015, 'The struggle against poverty, unemployment and social injustice in present-day South Africa: Exploring the involvement of the Dutch Reformed Church at congregational level', Stellenbosch involvement of the Dutch Reformed Church at congregational level', Stellenbosc
Theology Journal 1(2), 731-759. https://doi.org/10.17570/stj.2015.v1n2.a35

Vipond, H., 2012, Green exercise: Case studies, Scottish National Heritage, Edinburgh.

Western Cape Provincial Government of Social Development, 2012, Investing in the early years: Integrated provincial early childhood development strategy, Provincial Government of Social Development, Cape Town.

Weyers, M.L., 2011, The theory and practice of community work: A South African perspective, Xerox, PU for CHE, Potchefstroom.

White, B.P., 2009, Navigating the power dynamics between institutions and their communities, The Kettering Foundation, Washington, DC. 